\title{
Özel Gereksinimli Çocuklarda Ev Programlarının Uygulanmasını Etkileyen Faktörlerin İncelenmesi
}

Investigation of Factors Effecting The Applicability of Home Programme in Children With Special Needs

\section{Zeynep KAYA', Burcu Semin AKEL²}

${ }^{1}$ Erg., Ekrem Tok Ruh Sağlığı ve Hastalıkları Hastanesi,

2 Doç.Dr., Hacettepe Üniversitesi, Sağlık Bilimleri Fakültesi, Ergoterapi Bölümü, Ankara

\section{öz}

Amaç: Bu çalışma, özel gereksinimli çocuklar için verilen ergoterapi ev programlarının ebeveynler tarafından uygulanma sürecini etkileyen faktörleri incelemek amacıyla yapıldı. Gereç ve Yöntem: Ergoterapi müdahalesi kapsamında ev programı almakta olan özel gereksinimli 15 çocuğun ev programını uygulamayı üstlenen ebeveyni ile yarı yapılandırılmış görüşme yapıldı. Çalışmaya katılan özel gereksinimli çocuklar; serebral palsi, otizim spektrum bozukluğu ve öğrenme güçlüğü tanılarından birini almış çocuklardır. Çocukların yaş aralığı 5 ile 15 arasında rastgele dağıım gösterdi. Görüşmede verileri içerik (nitel) analizi ile çözümlendi ve temel sonuçlar kategorize edildi. Ebeveynlerin ev programı uygulamalarını etkilediğini belirten faktörler olumlu ya da olumsuz yönleriyle ortaya konuldu. Sonuç: Çalışmamıza katılan ebeveynlerin $\% 73,3$ ü anne, $\% 20$ si baba, \%6,7 si ise büyükanne idi. Ev programlarının tek bir yöntemle ebeveyne öğretilmesi, maddi yetersizlikler, ebeveynlerin ev programı hakkında stres yaşaması, programı uygularken çocukların ebeveynlere zorluk çıkarmaları, çocukların uygulama sırasında sıkılmaları, ebeveynlerin çok fazla fiziksel çaba harcıyor olmaları, ebeveynlerin iş ve üretici aktiviteleri, çocukların katılmakta olduğu diğer programlar, çocuğun gün içindeki ruh hali ve karakteristik özellikleri ev programı uygulamalarına olumsuz yansıyan faktörler olarak bulundu. Tartışma: Ergoterapist, ebeveynlere ev programı verirken bu faktörleri göz önünde bulundurmalı ve uygulamayı etkin kılacak öneriler ve modifikasyonlar yapmalı. Aile eğitimi kapsamında ev programlarının uygulanmasını denetlemelidir.

Anahtar Kelimeler: Ergoterapi; Ev programı; Aile katılımı; Özel gereksinimli çocuk

\section{A B S TRACT}

Purpose: This study is planned to analyze factors that effects the applicability of home programmes by parents to children with special needs. Material and Method: A semistructured interview was done with parents who are responsible of the occupational therapy home programme of 15 children with special needs. Children were diagnosed as cerebral palsy, autism spectrum disorder adn learning disability. Age range of the children was between 5- 15 years. Data was 
interpreted using Qualitative (content) analysis and was categorized. The factors parents reported was stated with positive and negative aspects. Results: Parents who participated to the study were mothers $(73,3 \%)$, fathers ( $20 \%)$ or grandmothers $(6,7 \%)$. Negative factors that effects parents to give home program were teaching home program by only one method, lack of economic conditions, stres of giving home program, unwillingness and boreness of children during giving home program, physical effort that perents spend, productive and work activities of parents, other therapies children need to take, mental status or personal characteristics of children. Conclusion: Occupational therapists need to consider these factors while giving home program to parents, make modifications or suggestions to make home program more effective. Occcupational therapists also need to observe how parents apply home programs.

Anahtar Kelimeler: Occupational therapy; Home program; Family participation; Children with special needs

\section{Giriş}

Özel gereksinimli çocuklar; fiziksel, gelişimsel, davranışsal ve emosyonel durumlarıyla ilgili kronik veya artmış bir risk altında bulunan ve sağlıkla ilişkili servislerden yararlanmaya intiyaç duyan çocuklardır (Stewart, Galvin, Froude, \& Lentin, 2010). Ergoterapi müdahalesi, özel gereksinimli çocukların fiziksel ve sosyal çevrelerinde fonksiyonel performanslarını ve yeteneklerini geliştirmek üzerine odaklanır (Case-Smith \& O'Brien, 2013). Ev programları istenilen bu gelişmeleri sağlamak için geniş ölçüde kullanılan bir stratejidir (Hinojosa \& Anderson, 1991).

Güncel bilgilere göre nöroplastisitenin gelişimi, yoğun bir şekilde yapılan pratik uygulamalarla artmaktadır. "Nöroplastisite, deneyimleri kodlamanın yanı sıra yeni davranış ve becerilerin öğrenilmesi için beynin adaptasyon kapasitesidir." (Kleim \& Jones, 2008). Ev programları, aileler ve terapistler tarafından terapi seanslarından arta kalan zamanlarda terapinin yoğunluğunu arttırmak için kullanılmaktadır (Novak \& Cusick, 2006). Ev programlarını çocuklar ve ebeveynlere yol gösterici bir yaşam biçimi olarak da düşünebiliriz (Novak, 2011). içerik olarak ev programı, ebeveyn yardımı ile ev ortamında gerçekleştirilen çocuğun sağlığı ile ilgili başarılı sonuçlara ulaşmak için belirlenmiş terapatik aktivitelerden oluşur (Novak, Cusick, \& Lowe, 2006).

20 yılı aşkın bir süredir ergoterapistlerce, çocuğun gelişiminde ailenin rolünün değeri giderek artmaktadır ve ailenin katıımı erken müdahale programlarının ayrılmaz bir parçasıdır (Case-
Smith \& O'Brien, 2013). Bu inanç ve uygulamanın bir uzantısı olarak ev programları, ailenin evde ergoterapi hedeflerine ulaşması için kabul gören bir yöntem haline gelmiştir (Dunn et al., 1989).

Ev programları terapistin desteği ve yönlendirmesi ile aile tarafından ev çevresinde uygulanır (Novak \& Cusick, 2006). Aile ile nasıl bir işbirliği kurulduğuna bağlı olarak ev programlarının etkinliği ve kullanışlıı̆̆ı artabilir. Etkili bir işbirliğine dayanılarak verilen ev programları için en iyi model, şu beş basamaktan oluşmaktadır: (1) ev çevresini ve çocuklarını en iyi tanıyan kişiler olarak ebeveynler ile işbirliği yapılması, (2) tedavi hedeflerinin çocuk ve aile tarafından belirlenmesi, (3) çocuk ve ailenin hedefleriyle eşleştirilmiş kanıta dayalı müdahalelerin seçilmesi ve aktiviteleri çocuğun tercihlerine ve aile rutinlerine göre düzenlemesi için ebeveynlere izin verilmesi; (4) gerektiğinde programın karmaşıklığının düzenlenmesi ve çocuktaki gelişmeleri fark edebilesi için aileye düzenli destek sağlanması, (5) sonuçların birlikte değerlendirilmesi (Novak et al., 2006)

Ev programlarının etkinliği tek bir parametre ile belirlenemez; hem programın içeriği hem de kişilerin bu programı nasıl uyguladığı incelenmelidir. Ev programı etkinliğini belirlemek birçok açıdan önemlidir. Etkili bir müdahale içeren ev programının tekrarlı olarak uygulanması tedavi modalitesi kadar önemli bulunmuştur (Straus, Richardson, Glasziou, \& Haynes, 2005) ve bu nedenle ev programlarını düzenli bir şekilde uygulayan aileler çocuklarının potansiyelini en üst seviyeye çıkarabilirler (Novak, 2011). 
Hedef odaklı eğitim ile verilen ev programlarının, serebral palsili çocukların motor becerilerini geliştirdiğine dair yüksek kalitede kanıtlar vardır (Katz-Leurer, Rotem, Keren, \& Meyer, 2009; Novak, Cusick, \& Lannin, 2009). Otizmli çocuklar için ebeveyn koçluğu ile verilen ev programlarının, çocukların kognitif becerilerinde gelişim sağladığına dair düşük kalitede kanıt vardır (Ozonoff \& Cathcart, 1998). Tayvan' da yapılan bir çalışmada aileler floortime yöntemi ile ergoterapistlerce eğitilmiş ve onlara bir ev programı verilmiştir. ÇaIışmanın sonucunda otizmli çocukların duyusal işleyiş, iletişim ve günlük yaşam becerileri üzerinde kayda değer gelişmeler elde edilmiştir (Liao et al., 2014). Bu çalışmalardan da anlaşıldığı gibi ergoterapi ev programlarının etkisi ve faydası sabit olarak belirlenmiş değildir. Ayrıca, programın yoğunluğunu belirlemek için terapiste yardım edecek az sayıda bilgi vardır ve ailenin katılımını arttırmak için ev programlarının niteliklerinin düzenlenmesinde terapiste yol gösteren bir rehber bulunmamaktadır (Novak \& Cusick, 2006).

Daha önce yapılan araştırmalarda ebeveynlerin ev programlarına uymasını ve programa devam etmelerini etkileyen faktörler olarak terapistin rolüne dair ailenin bakış açısı (Case-Smith \& Nastro, 1993; Hinojosa, 1990; Thompson, 1998), yeterli ebeveyn desteğinin önemi gösterilmiştir (CaseSmith \& Nastro, 1993; Washington \& Schwartz, 1996). Ev programlarının müdahalede önemli bir yeri olduğuna dair fikir birliği olsa da programın niteliklerinin, ailenin katılımına nasıl etki ettiğine dair kanıtlar yetersizdir (Novak \& Cusick, 2006). Ebeveynlerin ev programlarına katılımları, katıIım sürecini etkileyen faktörler ve etkin uygulayıp uygulamadıkları bilinmemektedir. Çalışmamızın amacı ailelerin ev programı uygulamalarını etkileyen faktörleri nitel desende incelemektir. Bu amaç doğrultusunda araştırma soruları düzenlenmiştir.

\section{GEREÇ VE YÖNTEM}

Bu çalışma, Hacettepe Üniversitesi Sağlık Bilimleri Fakültesi Ergoterapi Bölümü Duyusal İşlemleme ve Rehabilitasyonu Ünitesi ve Pediatri Ünitesi' nde ergoterapi müdahalesi almakta olan 15 çocuğun ebeveyni ile yapıldı. Çalışma 2015 yılı Şubat ve Mayıs ayları arasında uygulandı. Çocuklarda dahil edilme kriterleri; 18 yaşın altında olmak, özel gereksinimli çocuk tanımına uygun olmak ve ergote- rapi ev programı alıyor olmaktı. Ebeveynlerde ise ev programını uygulamayı üstlenen kişi olmak ve uygulamaya başlamış olmak kriter olarak belirlendi. Tüm katılımcılara çalışma ile ilgili bilgilendirme yapıldı ve çalışmaya gönüllü katıldıklarına dair onam formu imzalatıldı ve çalışmanın Helsinki Deklerasyonuna uygunluğu sağlandı.

Katılımcılara, araştırmacı tarafından hazırlanan yarı yapılandırıımış görüşme formu uygulandı. Bu form, literatür taramasından sonra araştırmacı tarafından düzenlendi. Katıımcıların bu sorulara verdiği yanıtlar olduğu gibi kayda geçirildi. Aşağıda bu formda yer alan sorular verilmiştir:

1. Ev programı almanızın yararları nelerdir?

2. Ev programı bir günde ne kadar sürüyor? Ev programı süresi hakkında ne düşünüyorsunuz?

3. Ev programı size ne şeklide/hangi yöntemle verildi? Bu şekilde verilmesinin programın uygulanmasına etkisini nasıl yorumluyorsunuz?

4. Ev programını size anlatıldığı şekilde uygulayabiliyor musunuz? Uygulayamama nedenleriniz nelerdir?

5. Ev programınızı uygularken kolaylaştırıcı durumlar nelerdir?

6. Ev programını uygulamanıza engel olan/ zorlaştıran durumlar nelerdir?

7. Ev programının uygulanmasıyla ilgili herhangi bir stres, kaygı/endişe duyuyor musunuz? Endişenizi açıklar mısınız?

8. Ev programının uygulanmasında isteksizlik/ bıkkınlık duyuyor musunuz? Nedenlerini açıklar mısınız?

9. Ev programının içeriğini değerlendirir misiniz?

10. Sizin ya da çocuğunuzun rutin alışkanlıkları ile ev programının uygulanması arasında bir ilişki oluyor mu?

11. Fiziksel ve sosyal çevrenin ev programı uygulanmasında etkisi nasıl?

12. Ev programı uygulamasının olumsuz yönleri nelerdir?

\section{İstatistiksel Analiz}

Verilerin istatistiksel analizi Windows tabanI SPSS 17.0 paket programı ile yapıldı. Ölçümle belirlenen değişkenler, aritmetik ortalama \pm stan-

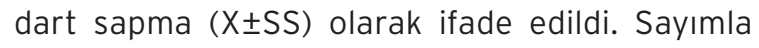
belirlenen değişkenler için yüzde (\%) değeri hesaplandı. Yarı yapılandırılmış görüşmede verilen 
sözel cevaplar bilgisayar ortamında Word belgesi haline getirildi ve nitel araştırma tekniklerden içerik analizi kullanılarak çözümlendi.

\section{SONUÇLAR}

Çalışmaya katılan ebeveynlerin yaş ortalaması $37,8 \pm 6,9$ yıl olarak bulundu. Katılımcıların tamamı evli olup, çocuğa yakınlık derecelerine göre $\% 73,3$ ü anne, $\% 20$ si baba ve $\% 6,7$ si büyükanne olarak belirlendi. Çalışmaya katılanların meslekleri $\% 73,3$ ev hanımı, $\% 13,3$ memur, $\% 13,3$ serbest meslek olarak dağılım gösterdi. Katılımcıların eğitim ve gelir durumları Tablo 1'de gösterilmiştir.

Ev programı uygulamasını etkileyen faktörler Tablo 2'de özetlenmiştir. Ebeveynler çoğunlukla iş ve üretici aktivitelerinin zaman açısından ev programını uygulamalarına olumsuz etkisi olduğunu ifade ettiler $(\% 53,3)$ : "Ev işleri çok zamanımı alıyor. Ev programı için zaman buluşturmaya çalışıyorum.", "Ev işlerini yapınca programı uygulayamıyoruz.", "Zaman açısından olumsuz etkiliyor."

Ebeveynlerin çoğu eğitim durumlarının ev programını uygulamalarına etki etmediğini $(\% 53,3)$, bunun daha çok uygulamayı anlayıp kişinin bu konuda kendini eğitmesi ile ilgili olduğunu ifade etti: "Eğitim durumuyla alakalı olduğunu düşünmüyorum. Anlayıp uygulamakla alakalı.", "Önemli olan kişinin kendini eğitmesi. Bu işin içine girdiğimden beri biraz daha bilgi sahibiyim."

Gelir seviyesini "orta" olarak tanımlayan ebeveynler çoğunlukta olup $(\% 86,7)$, gerekli malzemeleri temin etmede zorlandıkları için maddi durumlarından olumsuz yönde etkilendiklerini belirttiler (\%46,7): "Bazı malzemeler çok pahalı.", "Malzemeleri temin etmem uzun sürdü.", "Materyallerin hepsini alamadım."

Genel olarak aileler çocukla olan ilişkilerini "iyi" olarak tanımladı (\%46.7). Ebeveynlerin çoğu, çocuklarıyla olan ilişkilerinin iyi olmasının ev programı uygulamalarına olumlu yönde yansıdığını ifade etmiştir (\%53,3): "4/4 lük tamamlıyorum.", "En iyi benimle iletişim kurduğu için ben daha iyi uyguluyorum." Bazı ebeveynler ise iyi olan ilişkilerinin çocukları tarafından kullanıldığını ve söylediklerini yapmadıklarını belirttiler (\%33,3): “Naz yapıyor. Kaytardığı oluyor.", "Aramızın iyi olmasını kullanıyor. Komut alma konusunda insan seçiyor. Bizden komut almıyor."

Tablo 3' de ev programı verilme şekillerinin yüzde dağılımı gösterilmiştir. Birden fazla yöntemle verilen ev programları, ebeveynler için uygulamayı olumlu yönde etkileyen bir faktör olarak görüldü. Özellikle sözel anlatımın yanında yazılı ve şekilli olarak verilmesinin uygulamayı nasıl yapacaklarını daha iyi anlayıp gerektiğinde hatırlamaIarına yardımcı olduğunu belirttiler: "Unutunca neydi diye bakıyorum.", "Bazılarını anlayamamıştım, şekiller faydalı oldu. Unuttuğumda kağıttan baktım." Sadece sözel anlatım yoluyla verilen ev programlarında ebeveynler bu yöntemle verilmesinin uygulamalarına olumsuz yönde etki ettiğini ifade ettiler (\%40): "Sözel olanların çoğunu unuttum. Daha iyi anlayabilmem için görsel olarak görmem gerekiyor.", "Fırçalamayı yanlış yapıyormuşum. Sözel olunca yanlış anlaşılma oluyor. Görsel daha farklı. Keşke video olsaydı."

Çalışmaya katılan çocuklar 20,2 $\pm 28,4$ haftadır ev programı almaktadır (Tablo 4). Ev programını uygulamaya başlama zamanı ebeveynler tarafından, uygulamalarına olumlu yönde etki ettiği ifade edildi $(\% 66,7)$. Ebeveynlerin çoğu ev programının çocuklarında gelişme sağladığını ve gitgide uygulamalarının kolaylaştığını söyledi: "Çocuğun gelişiminin hızlandığını fark ediyorum.", "Çocuğun farkındalığı, dil gelişimi, etrafına ilgisi arttı, sıralı oyunları arttı.", "Çocuğumun algılaması toparlandı. Arabada gelirken dışarıyı seyretmeye başladı."

Ebeveynlerin çoğu şu anki uygulama sürelerinin uygulamalarına olumlu yönde yansıdığını belirtti $(\% 73,3)$. Çocuklarının bu kadarını kaldırabildiklerini ve onlar için ideal olan sürenin bu olduğunu söylediler: “Efe için yeterli.", "Arda bu kadar müsaade ediyor."

Ebeveynlerin gün içerisinde çocuklarıyla birlikte geçirebildikleri zamanın ortalaması 8,3 $\pm 8,3$ saat olarak bulundu. Bu sürenin uzun olması ev programını uygulamalarını olumlu yönde etkilediğini şu ifadelerle belirttiler (\%60): "Yaptığım şeylere onu da dahil ediyorum.", "Destekleyen bir şey."

Ebeveynler, çocuklarının kardeşi olma durumunu onlardan görerek taklit etmesi ve onlarla daha iyi iletişim kurup daha çok keyif almaları nedeniyle olumlu olarak nitelendirdiler $(\% 33,3)$ : "Ablasını taklit ediyor. Onunla daha çok iletişim içinde.", "Örneklemesi fazla. Kardeşinden görünce daha iyi yapıyor." Kardeşi olmasını bir dezavantaj olarak gören ebeveynler ise bu durumu daha 
Tablo 1. Katılımcıların eğitim ve gelir durumu.

\begin{tabular}{|c|c|c|c|}
\hline \multirow{4}{*}{ Eğitim Durumu } & & Frekans & Yüzde \\
\cline { 2 - 4 } & ilkokul & 2 & 13,3 \\
\cline { 2 - 4 } & Lise & 5 & 33,3 \\
\cline { 2 - 4 } & Ön lisans & 2 & 13,3 \\
\cline { 2 - 4 } & Lisans & 5 & 33,3 \\
\hline \multirow{3}{*}{ Gelir Durumu } & Doktora & 1 & 0 \\
\cline { 2 - 4 } & Düşük & 0 & 86,7 \\
\cline { 2 - 4 } & Orta & 13 & 13,3 \\
\hline
\end{tabular}

Tablo 2. Ev programını etkileyen faktörler ve etkileme şeklinin yüzde dağıımı

\begin{tabular}{|c|c|c|c|c|}
\hline Etkenler & Etkisi Yok & Olumlu & Olumsuz & Her ikisi \\
\hline Uygulamaya başlama zamanı & $\% 13,3$ & $\% 66,7$ & $\% 6,7$ & $\% 13,3$ \\
\hline Uygulama süresi & $\% 13,3$ & $\% 73,3$ & $\% 13,3$ & \\
\hline Programın verilme şekli & $\% 6,7$ & $\% 53,3$ & $\% 40$ & \\
\hline Kardeş durumu & $\% 33,3$ & $\% 33,3$ & $\% 33,3$ & \\
\hline Çocuk ile geçirilen vakit & $\% 20$ & $\% 60$ & $\% 20$ & \\
\hline Çocuk ile olan ilişki & $\% 0$ & $\% 53,3$ & $\% 33,3$ & $\% 13,3$ \\
\hline Gelir düzeyi & $\% 20$ & $\% 33,3$ & $\% 46,7$ & \\
\hline Eğitim durumu & $\% 53,3$ & $\% 40$ & $\% 6,7$ & \\
\hline Hissedilen stres düzeyi & $\% 40$ & $\% 13,3$ & $\% 46,7$ & \\
\hline Yararlılığına olan inanç & $\% 20$ & $\% 80$ & $\% 0$ & \\
\hline Duyulan isteksizlik düzeyi & $\% 60$ & $\% 6,7$ & $\% 33,3$ & \\
\hline Çocuğun sıkılma düzeyi & $\% 33,3$ & $\% 6,7$ & $\% 60$ & \\
\hline Günlük ruh hali ve karakter & $\% 20$ & $\% 6,7$ & 73,3 & \\
\hline Çocuğun zorluk çıkarma durumu & $\% 33,3$ & $\% 6,7$ & $\% 60$ & \\
\hline Sarf edilen fiziksel efor & 46,7 & $\% 0$ & $\% 53,3$ & \\
\hline Uyku sağlığı & $\% 73,3$ & $\% 0$ & $\% 26,7$ & \\
\hline Rutin aktiviteler & $\% 66,7$ & $\% 0$ & $\% 33,3$ & \\
\hline İş ve üretici aktiviteler & $\% 46,7$ & $\% 0$ & $\% 53,3$ & \\
\hline Çocuğun katıldığı diğer programlar & $\% 40$ & $\% 6,7$ & $\% 53,3$ & \\
\hline Ev çevresi ve fiziksel çevrenin etkisi & $\% 33,3$ & $\% 40$ & $\% 26,7$ & \\
\hline Evde yaşayan kişi sayısı & $\% 46,7$ & $\% 40$ & $\% 13,3$ & \\
\hline Çevrenizdeki bireyler & $\% 53,3$ & $\% 46,7$ & $\% 0$ & \\
\hline Sosyal çevre ile vakit geçirme & $\% 53,3$ & $\% 6,7$ & $\% 40$ & \\
\hline
\end{tabular}


Tablo 3. Ev programının ebeveynlere verilme şeklinin dağılımı.

\begin{tabular}{|c|c|}
\hline Ev Programının Verilme Şekli & Oran \\
\hline Video & $\% 0$ \\
\hline Sözel Anlatım & $\% 33,3$ \\
\hline Yazılı & $\% 0$ \\
\hline Uygulamalı Gösterme & $\% 6,7$ \\
\hline Birden Fazla Yöntem & $\% 60$ \\
\hline
\end{tabular}

Tablo 4. Ev programı ve çocuk ile geçirilen vakit süreleri.

\begin{tabular}{|c|c|}
\hline Soru & Ortalama Süre \\
\hline Ev programını ne zamandan beri uyguluyorsunuz? & $20,2 \pm 28,4$ hafta \\
\hline Ev programı bir günde ne kadar sürüyor? & $51,6 \pm 48,9$ dakika \\
\hline Bir günde çocuğunuzla ne kadar vakit geçirebiliyorsunuz? & $8,3 \pm 8,3$ saat \\
\hline
\end{tabular}

çok onların da ilgi ve zaman ayrılmaya intiyaçları olmasına bağladılar (\%33,3): "Zaman açısından sıkıntı oluyor. Programı uygularken kardeşi yalnız kalıyor.", "Kardeşleri de ilgi istiyorlar.", "Kardeşinin ikinci plana düşmesini istemiyoruz."

Ebeveynlerde ve çocuklarında büyük oranda uyku problemi görülmediği $(\% 73,3)$ belirlendi ve kişilerin uyku sağlıklarının ev programı uygulamalarına etkisi olmadığı şeklinde yanıt alındı $(\% 73,3)$.

Çalışmamıza katılan tüm ebeveynlerin çocukları ergoterapinin yanında başka programlara da düzenli olarak katılmaktadır. Bu programların ev programının uygulanmasına etkisi, zaman problemi ve yorgunluk oluşturması bakımından çoğunlukla olumsuz olarak görüldü $(\% 53,3)$ : “Gittiğimiz günler yorgunluktan yaptıramıyoruz.", "Gidiyorsun, geliyorsun, yoruluyorsun.", "Çocuğumun çok yoğun bir programı var.", "Zaman açısından sıkıntı oluyor."

Ebeveynlerin büyük çoğunluğu ev programının uygulamasıyla ilgili stres yaşadıklarını ve bu durumun daha çok uygulamayı olumsuz etkilediğini belirttiler (\%46,7): “Tam anlamıyla uygulayamadığım için, tam anlatılmadığı için bir karmaşa yaşıyorum içimde.", “Ona verimli olamayacağım diye endişeleniyorum. Bu endişeden dolayı bazen yapmaktan vazgeçiyorum." Bunun yanında stres hissetmelerine rağmen bunun uygulamalarını etkilemesine izin vermeyen ebeveynler de vardı (\%40): "Çocuğum sakin olmadığı zamanlar stres yapıyorum. Uygulamayı babasına devrediyorum."

Ebeveynlerin büyük çoğunluğu ev programının yararlılığına inandığını ve bu inancının ev programı uygulamalarına olumlu yansıdığını ifade etti (\%80): “iyi bir şey yaptığımı düşünerek yapıyorum."

Ebeveynler ev programının uygulanması ile ilgili bazı zamanlarda isteksizlik duyduklarını ve bu durumun aynı şeyleri tekrarlamaktan kaynaklandığını ifade ettiler. İsteksizlik duyduklarında programa olumsuz yansımasının nedenlerini verimliliğinin düşmesine veya uygulamayı sonlandırıyor olmalarına bağladılar (\%33,3): “Uygulamayı bırakıyorum ya da verimliliği düşüyor.", "Uygulamaktan vazgeçiyorum. Başka bir şey yapıyoruz. Gezmeye götürüyorum." Ebeveynlerin büyük bir kısmı isteksizlik duymalarının ev programı uygulamalarını etkilemediğini söylerken bunu daha çok çocuklarındaki gelişmeleri görüp enerji bulmalarına ve kendilerini toparlamalarına bağladı (\%60): 
"Sürekli aynı şeyi tekrarlamak gibi ama çocuğumun ilerlemesi beni kendime getiriyor.", "Öğrendiğini görmek enerji kaynağı oluyor. Eşim devreye giriyor."

Ebeveynler ev programını uygularken çocuklarının sıkıldıklarını ve bu durumun uygulamaya ara vermelerine, uygulamayı sonlandırmalarına ya da uygulama verimliliğinin düşmesine neden olduğunu ifade ettiler (\%60): "Başka bir şey yapmak istiyor. Yorulmak istemiyor. Yapmıyoruz.", "Oyun odakıı bir çocuk, sıkıntıya gelemiyor. Ara vermek zorunda kalıyorum.", "Sevdiği şeyler değil, ilgi çekici değil. Taktil kaçınmasından dolayı rahatsız oluyor."

Ebeveynler, ev programını uygulama sırasında çocuklarının onlara zorluk çıkardığını ve bundan dolayı uygulamanın verimliliğinin düştüğünü, uygulamayı azaltmak veya bitirmek zorunda kaldıklarını ve olumsuz etkilendiklerini belirttiler (\%60): "Hata yapma, oyunu başlatamama oluyor. Uygulamayı azaltıyorum. Zamanını değiştiriyorum.", "Gene de yapıyoruz ama verimliliği düşüyor.", "itiraz ediyor. Bazen üzerine gidip yapıyoruz, bazen bırakıyoruz."

Ebeveynler çok fazla fiziksel efor sarf etmelerinden dolayı yorgunluk açığa çıktığında ev programı uygulamalarının olumsuz etkilendiğini belirtti $(\% 53,3)$ : "Uygulasak da verimlilik düşüyor.", "Devam ediyoruz ama kalitesi düşüyor.", "Yorulunca yapamıyoruz."

Ebeveynlerin büyük çoğunluğu, çocuklarının karakteristik özellikleri veya o günkü ruh hallerinden ötürü programı gerektiği gibi uygulayamayıp sonlandırmak zorunda kaldıklarını ifade ettiler: "Hasta ve huysuz olduğu zaman yapabildiğim kadar yapıyorum. Onu rahatsız etmeyecek şekilde yapıyorum.", "Hırçınlık, sinirlilik, inatçılık oluyor. Bu yüzden yarıda bıraktığım oluyor.", "Inatçılık var. Yapmak istemiyorsa yapmaz."

Ebeveynlerin çoğu, hayatlarında öncelik olarak çocuklarını gördükleri ve yaşamlarını onlara göre düzenledikleri için rutin aktivitelerinin ev programlarına etkisi olmadığını söyledi $(\% 66,7)$ : "Rutinlerimiz yok. Önceliğimiz Yiğit.", "Evde herşeyi bırakıyoruz.", "Çocuk odaklı yaşıyoruz."

Ebeveynlerin ev çevresi ve fiziksel çevreyi çocuklarına uygun şekilde dizayn ettikleri ve bunun ev programı uygulamasına olumlu yönde etki ettiği saptandı (\%40). Ebeveynler tarafından
"Evi Yiğit'e göre düzenledik.", “Çocuklara göre dizayn ettik." ifadeleri kullanıldı. Bununla birlikte evin fiziksel çevresi ev programı uygulamalarına olumsuz yansıyan ebeveynlerin bunun sebebini evlerinin küçük olması olarak açıkladığı görüldü (\%26,7): "Ev küçük, salon küçük. Rahat rahat koşamıyorlar.", "Berbat. Evimiz çok küçük.", “Ev küçük. Ayrı odası yok."

Çalışmaya katılan ebeveynlerin evde yaşayan kişi sayısı ortalama 3,8 $\pm 0,6$ olarak belirlendi. Ebeveynlerin çoğu, evde yaşayan kişi sayısının ev programını uygulamalarına etki etmediğini düşünüyor $(\% 46,7)$.

Çevrelerindeki bireylerin ev programını uygulamalarına etkisinin olmadığını savunan ebeveynlerin çoğunlukta olduğu görülmektedir $(\% 53,3)$. Yadsınamayacak bir oranda da çevrelerindeki kişilerin uygulamalarına olumlu etkisi olduğunu söyleyen ebeveynler tespit edildi (\% 46,7): "Misafirliğe gittiğimizde kuzenleri yaptırıyor.", "Komşular yardım ediyorlar."

Ebeveynler genellikle sosyal çevreleri ile vakit geçirmelerinin ev programı uygulamalarına etkisi olmadığını ifade etti $(\% 53,3)$. Bu konuda da daha çok önceliği çocuklarına verdikleri için sosyal çevreleriyle vakit geçirmediklerini belirttiler: "Öncelik çocuğumun.", "Vakit geçirmiyoruz.", "Gelen giden fazla olmuyor."

\section{TARTIŞMA}

Ev programlarına ailenin katıımı uzun yıllar önce araştırma konusu olmuştur. Serebral palsili çocuklarla yapılan çalışmada ailenin katııımı ile çocukların gelişimsel kazanımları arasında anlamlı ilişki bulunmuştur (Parette \& Hourcade, 1985).

Çalışma sonuçlarımıza göre aileler ev programlarını yararlı görmektedirler $(\% 93,3)$; fakat etkin bir şekilde uygulayamama nedenleri arasında ev programının sadece sözel anlatım yöntemi ile verilmesi, gelir durumlarının yetersizliği, ev programı uygulaması ile ilgili stres yaşamaları, çocuğun ev programı uygulaması sırasında sıkılıyor olması, çocuğun o gün içindeki ruh hali ve karakteristik özellikleri, çocuğun uygulama sırasında kendilerine zorluk çıkarıyor olması, çok fazla fiziksel efor sarf ediyor olmaları, iş ve üretici aktivitelerinin programa zaman ayırmalarını zorIaştırması, çocuğun başka programlara katılıyor olması bulunmaktadır. 
Bir çok ebeveyn ev programındaki aktiviteleri doğru uygulayıp uygulamadıkları konusunda bir miktar stres yaşamaktadır (Case-Smith \& Nastro, 1993). Bizim çalışmamızda ebeveynlerin yaşadığı stresin ev programı uygulamalarını olumsuz etkilediği belirlendi. Ayrıca ev programı, sadece sözel olarak anlatıldığında ebeveynlerin programı anlaması ve programın akılda kalıcı olması zorlaşmaktadır. Bu nedenle ev programı verilirken programının içerdiği aktivitelerin ebeveyne anlatılması sırasında birden fazla yöntem bir arada kullanılmalı ve hatırlatıcı olması amacıyla gerekirse yazılı ve şekilli bir broşür hazırlanmalıdır. Böylece aileler ev programının nasıl uygulanacağını daha iyi anlayıp uygulama sırasında da yararlanabilecekleri bir materyale sahip olacaklar ve acaba doğru mu uyguluyorum diye stres yaşamayacaklardır.

Ergoterapistin ev ziyareti yaparak ailenin uygulamasını gözlemlemesi ve ev programını kontrol etmesi de uygulanabilecek bir yöntemdir. Çalışmamıza katılan ebeveynlerin $\% 46,7$ si ev programlarının kontrol edilmediğini ifade etti. Ergoterapist ev programlarının takibini yapmalı ve aile ile işbirliği içerisinde olmalıdır. Nitekim daha önce yapılan bir çalışmaya göre ev programıyla ilgili memnuniyetlerinin terapist tarafından takip edilmesi ebeveynlerin ev programına bağlılığını arttırmaktadır (Wuang, Ho, \& Su, 2013). Başka bir çözüm önerisi olarak ergoterapist, bakım veren eğitimi kapsamında ev programını üstlenen bireye stresle başa çıkma becerileri eğitimi verebilir.

Türk toplumunda çocuk bakımı daha çok annelerin görevi olarak görülmektedir ve genellikle anneler bir işte çalışmazlar ve ev hanımıdırlar. Bu gibi nedenlerle ev programlarının uygulanması daha çok anneler tarafından üstlenilmiştir. Hacettepe Üniversitesi'nde yapılan bir çalışmada çocukların bakımı, rehabilitasyon ve ev programlarının babadan ziyade anneler tarafından takip edildiği ortaya konulmuştur (Mutlu, Tarsuslu, Günel, \& Livanelioğlu, 2007). Bizim çalışmamızda katılımcıların \%73,3 ünün anne rolünde olması da bu görüşü destekler niteliktedir. Bu sebeple tüm gün çocuğuyla ilgilenen ve ev işlerini yapmakla yükümlü olan anneler aynı zamanda diğer çocuklarıyla da ilgilenmek istemektedir. Çalışmamızda ev programı almakta olan çocukların \%73,3 ünün kardeşi olduğu belirlendi. Kardeşlerinin de zaman ayrılmaya intiyacı olması aynı zamanda ebeveynlerin yapmakla yükümlü olduğu ev işleri nedeniyle ev programı uygulamaları olumsuz etkilenmektedir. Burada çözüm olarak ergoterapist hem anne hem de baba ile görüşerek ev programının uygulanması konusunda görev dağılımı yapıımasını sağlayabilmelidir.

Çalışmamıza katılan ailelerin ortalama gelir düzeyleri, \%86,7 oranında "orta" olarak tanımlansa da ev programı için gereken materyallerin temin edilmesinde zorlandıkları ve bunun da uygulamalarına olumsuz olarak yansıdığı ortaya konuldu. Bu materyallerin tedavi sürecinde devlet tarafından karşılanması için yasa çıkarılması ailelerin sağlık hizmetinden daha iyi yararlanmalarını sağlayacaktır.

Çalışmamızın sonucuna göre ev programlarının uygulaması sırasında hem ebeveynler hem de çocuklar sıkılmakta ve bu durum uygulamayı olumsuz etkilemektedir. Bunun önlenmesi için ergoterapist ev programının içeriğindeki aktiviteleri belli aralıklarla değiştirmeli aktiviteleri modifiye edebilmesi için ebeveyne çeşitli öneriler sunabilmelidir.

Ev programlarına ailenin katılımını kolaylaştırıcı bir faktör olarak ebeveyn-çocuk ilişkisi gösterilebilir. Çocuğun bulunduğu dönemdeki kazanımIarı, ev programında hoşlandığı aktivitelerin yer alması, bu aktivitelerin miktarı ve ailenin günlük yaşamına adapte edilebilir olması ailenin ev programına katıımını arttırıcı özelliklerdir (Hinojosa \& Anderson, 1991). Çalışmamızda literatüre paralel sonuçlar elde edildi. Ebeveyn çocuk ilişkisinin iyi olması, ev programının gün içerisindeki uygulama süresi, ailelerin günlük yaşamlarını çocuklarına göre düzenlemeleri, ebeveynlerin çocuklarındaki gelişimlere tanık olmaları, program içeriğinde çocuğun sevdiği aktivitelerin yer alması uygulamaları olumlu yönde etkiledi.

Ev programının başarılı olarak uygulanması ailenin eğitim seviyesinden, evde programını payIaşımlı olarak uygulayabilmesinden, evdeki çocuk sayısından etkilendiği sonucunu veren bir çalışma bulunmaktadır (Case-Smith \& Nastro, 1993). Bizim çalışmamızda katıımcıların \%53,3 ü eğitim durumlarının ev programı uygulamalarında herhangi bir etkisi olmadığını savundular. Bunu da "Eğitim durumuyla alakalı olduğunu düşünmüyorum. Anlayıp uygulamakla alakalı.", "Önemli olan kişinin kendini eğitmesi. Bu işin içine girdiğimden 
beri biraz daha bilgi sahibiyim." ifadeleriyle açıkladılar. Çalışmamızda evdeki çocuk sayısının uygulamalarına etkisi olumlu ve olumsuz olarak eşit bir dağılım gösterdi.

Çalışmamız, ev programlarının daha iyi uygulanması için yol gösterici bir çalışma olmuştur. Katılımcılardan alınan ortak ifadelere göre hayatlarını çocuklarına göre düzenledikleri, sosyal çevreleriyle vakit geçiremedikleri ve rutin aktivitelerinin olmadığı bulundu. Özel gereksinimli çocukların ailelerinde rol aktivite dengesinin ve farklı bölgelerde yaşayan ailelerin tutumlarının incelenmesi önerilmektedir.

\section{K AYNAKLAR}

Case-Smith, J., \& Nastro, M. A. (1993). The effect of occupational therapy intervention on mothers of children with cerebral palsy. Am $J$ of Occup Ther, 47(9), 811-817.

Case-Smith, J., \& O'Brien, J. C. (2013). Occupational therapy for children: Elsevier Health Sciences.

Dunn, W., Campbell, P., Oetter, P., Hall, S., Berger, E., \& Strickland, R. (1989). Guidelines for occupational therapy services in early intervention and preschool services. Rockville, MD: American Occupational Therapy Association.

Hinojosa, J. (1990). How mothers of preschool children with cerebral palsy perceive occupational and physical therapists and their influence on family life. OTJR: Occupation, Participation and Health, 10(3), 144-162.

Hinojosa, J., \& Anderson, J. (1991). Mothers' perceptions of home treatment programs for their preschool children with cerebral palsy. Am $J$ of Occup Ther, 45(3), 273-279.

Katz-Leurer, M., Rotem, H., Keren, O., \& Meyer, S. (2009). The effects of ahome-based'task-oriented exercise programme on motor and balance performance in children with spastic cerebral palsy and severe traumatic brain injury. Clin Rehabil, 23(8), 714-724.

Kleim, J. A., \& Jones, T. A. (2008). Principles of experiencedependent neural plasticity: implications for rehabilitation after brain damage. Journal of Speech, Language, and Hearing Research, 51(1), S225-S239.

Liao, S.-T., Hwang, Y.-S., Chen, Y.-J., Lee, P., Chen, S.J., \& Lin, L.-Y. (2014). Home-based DIR/Floortime ${ }^{T M}$ Intervention Program for Preschool Children with Autism Spectrum Disorders: Preliminary Findings. Phys Occup Ther Pediatr, 34(4), 356-367.
Mutlu, A., Tarsuslu, T., Günel, M. K., \& Livanelioğlu, A. (2007). Serebral paralizili çocuklarda ev egzersiz programının etkinliğinin incelenmesi Orijinal Araştırma. Türk Pediatri Arşivi, 42(3).

Novak, I. (2011). Parent experience of implementing effective home programs. Phys Occup Ther Pediatr, 31(2), 198-213.

Novak, I., \& Cusick, A. (2006). Home programmes in paediatric occupational therapy for children with cerebral palsy: Where to start? Aust J of Occup Ther, 53(4), 251-264.

Novak, I., Cusick, A., \& Lannin, N. (2009). Occupational therapy home programs for cerebral palsy: doubleblind, randomized, controlled trial. Pediatrics, 124(4), e606-e614.

Novak, I., Cusick, A., \& Lowe, K. (2006). A pilot study on the impact of occupational therapy home programming for young children with cerebral palsy. The American Journal of Occupational Therapy: official publication of the American Occupational Therapy Association, 61(4), 463-468.

Ozonoff, S., \& Cathcart, K. (1998). Effectiveness of a home program intervention for young children with autism. $J$ Autism Dev Disord, 28(1), 25-32.

Parette, H. P., \& Hourcade, J. J. (1985). Parental participation in early therapeutic intervention programs for young children with cerebral palsy: an unresolved dilemma. Rehabilitation Literature.

Stewart, J., Galvin, J., Froude, E. H., \& Lentin, P. (2010). Evaluation of the Australian adaptation of the Keeping It Together (KIT-Australia) information package with carers of children with special needs. [Evaluation Studies

Research Support, Non-U.S. Gov't]. Aust Occup Ther J, 57(4), 268-275. doi: 10.1111/j.14401630.2010.00858.x

Straus, S. E., Richardson, W. S., Glasziou, P., \& Haynes, R. B. (2005). Evidence-based medicine: how to practice and teach EBM.

Thompson, K. M. (1998). Early intervention services in daily family life: mothers' perceptions of 'ideal'versus 'actual'service provision. Occup Ther Int, 5(3), 206221.

Washington, K., \& Schwartz, I. S. (1996). Maternal Perceptions of the Effexts of Physical and Occupational Therapy Services on Caregiving Competency. Phys Occup Ther Pediatr, 16(3), 33-54.

Wuang, Y.-P., Ho, G.-S., \& Su, C.-Y. (2013). Occupational therapy home program for children with intellectual disabilities: A randomized, controlled trial. Research in Developmental Disabilities, 34(1), 528-537. 
